\title{
ANALISIS PERBANDINGAN RISIKO USAHATANI PADI SAWAH DAN PADI RAWA \\ (Suatu Kasus Di Desa Sukanagara Kecamatan Lakbok Kabupaten Ciamis)
}

COMPARATIVE ANALYSIS OF RISK OF FARMING RICE AND SWAMP RICE

(A Case in Sukanagara Village, Lakbok District, Ciamis Regency).

\author{
MEIZA MAGFIRA ${ }^{1^{*}}$,TRISNA INSAN NOOR ${ }^{2}$, DANI LUKMAN HAKIM ${ }^{1}$ \\ ${ }^{1}$ Fakultas Pertanian Universitas Galuh \\ ${ }^{2}$ Fakultas Pertanian Universitas Padjajaran \\ *E-mail : meizamagfira@gmail.com
}

\begin{abstract}
ABSTRAK
Penelitian ini dilaksanakan dengan tujuan untuk mengetahui : (1) Berapa besarnya biaya, penerimaan dan pendapatan usahatani padi sawah dan padi rawa di Desa Sukanagara Kecamatan Lakbok Kabupaten Ciamis. (2) Bagaimana risiko usahatani padi sawah dan padi rawa di Desa Sukanagara Kecamatan Lakbok Kabupaten Ciamis. (3) Apakah terdapat perbedaan nyata risiko usahatani padi sawah dan padi rawa di Desa Sukanagara Kecamatan Lakbok Kabupaten Ciamis. Jenis penelitian yang digunakan adalah metode survey dengan mengambil suatu kasus di Desa Sukanagara Kecamatan Lakbok Kabupaten Ciamis, Responden dalam penelitian ini adalah petani yang melalukan usahtani padi di lahan sawah dan di lahan rawa di Desa Sukanagara yang diambil secara acak sederhana (Simple Random Sampling). Hasil dari penelitian menunjukkan bahwa Biaya Total yang dikeluarkan pada usahatani padi di lahan sawah dan dilahan rawa di Desa Sukanagara tidak jauh berbeda, namun untuk penerimaann pada MT 1 dan MT 2 usahtani padi di lahan sawah lebih besar dibandingkan dilahan rawa. Pendapatan pada Usahatani padi sawah lebih besar dibandingkan pendapatan padi rawa. Risiko usahatani padi sawah lebih kecil dibandingkaan padi rawa. Hasil Analisis uji hipotesis menunjukan bahwa risiko produksi dan risiko pendapatan pada usahtani padi dilahan sawah maupun rawa berbeda secara signifikan (nyata). Sedangkan untuk risiko harga pada usahatani pada lahan sawah dan rawa tidak terdapat perbedaan signifikan (tidak nyata).
\end{abstract}

Kata Kunci : Padi rawa, padi sawah, risiko Harga, risiko pendapatan, risiko produksi

\begin{abstract}
This research was conducted aimed to find out: (1) the costs, revenues and income of rice and swamp rice farming in Sukanagara Village, Lakbok District, Ciamis Regency. (2) the risk of rice and swamp rice farming in Sukanagara Village, Lakbok District, Ciamis Regency. (3) a real differences in the risk of lowland rice and swamp rice farming in Sukanagara Village, Lakbok District, Ciamis Regency. The method survey research by taking a case in Sukanagara Village, Lakbok Subdistrict, Ciamis Regency. Respondents in this study were farmers who carried out rice farming in paddy fields and in swamps in Sukanagara Village, which were taken by simple random sampling. The results of the study showed that the total costs incurred on rice farming in paddy fields and swamp land in Sukanagara Village were not much different, but for MTn and MT 2 revenue the rice farming in paddy fields is greater than in swamp land. So that the income on the paddy farming was greater than the income of swamp rice. The risk of lowland rice farming was smaller than that of swamp rice. The results of the hypothesis test analysis show that production risk and income risk in rice and swamp farming were significantly different. As for the price risk of farming on paddy fields and swamps there was no significant difference (not significant).
\end{abstract}

Keywords: Income risk, price risk, production risk, lowland rice, swamp rice 
PENDAHULUAN

Sektor pertanian mempunyai konstribusi yang besar dalam pembangunan perekonomian. Secara sektoral, sektor pertanian terdiri atas subsektor pertanian tanaman pangan, subsektor perkebunan, subsektor perternakan, subsektor perikanan, dan subsektor kehutanan. Diantara semua subsektor, subsektor tanaman pangan khususnya padi merupakan penghidupan bagi masyarakat. (Rahim, 2012)

Sektor pertanian banyak memiliki manfaat bagi masyarakat Indonesia dan negara lain karena mayoritas masyarakat Indonesia bermata pencaharian sebagai petani, komoditas berpengaruh terhadap gizi dan kesehatan penduduk terutama melalui produksi pangan yang dikonsumsinya. Pangan dimaksud pertanian merupakan sumber pangan bagi manusia yang akan memberikan gizi yang bermanfaat bagi pertumbuhan dan kesehatan manusia (Sutanto, 2012).

Padi merupakan sumber pangan utama penduduk Indonesia yang sebagian besar dibudidayakan sebagai padi sawah. Pada umumnya, padi juga merupakan salah satu komoditi yang mempunyai prospek cerah guna menambah pendapatan para petani. Hal tersebut dapat memberikan motivasi tersendiri bagi petani untuk lebih mengembangkan dan meningkatkan produksinya dengan harapan agar pada saat panen petani memperoleh hasil penjualan tinggi guna memenuhi kebutuhannya Namun kadang kala dalam kenyataannya berbicara lain. Ketika saat panen tiba, hasil melimpah tetapi harga mendadak turun, dan lebih parah lagi jika hasil produksi yang telah dipersediakan jauh melenceng dari jumlah produksi yang dihasilkan, produksi minim, harga rendah dan tidak menentu membuat petani padi kadang merasa kecewa bahkan patah semangat untuk tetap mengembangkan usaha pertaniannya. Hal ini disebabkan karena setiap kegiatan pengolahan sawah mutlak petani mengeluarkan biaya untuk kegiatan produksi. Mulai dari pengadaan bibit, pupuk, pengolahan, pestisida dan biaya lainnya yang tidak terduga.

Dalam berbagai kegiatan usaha di bidang pertanian sering terjadi situasi ekstrim, yaitu kejadian yang mengandung risiko (risk events) dan kejadian yang tidak pasti (uncertainty events). Risiko produksi pertanian lebih besar dibandingkan risiko non pertanian, karena pertanian sangat dipengaruhi oleh alam seperti cuaca, hama penyakit, suhu, kekeringan, dan banjir. Selain alam, risiko dapat ditimbulkan oleh kegiatan pemasaran. Risiko harga disebabkan karena harga pasar tidak dapat dikuasai petani. Fluktuasi harga lebih 
sering terjadi pada hasil-hasil pertanian. Menurut Widodo (2006) risiko dapat bersumber pada siklus bisnis, fluktuasi musiman, inflasi, iklim, hama penyakit, nilai tukar rupiah, dan teknologi. Sementara itu menurut Kay (1981) sumber risiko dan ketidakpastian bidang pertanian diantaranya adalah production and technical risk yaitu risiko produksi yang terjadi oleh adanya hubungan teknis antara output dan tingkat penggunaan input, harga, finansial, kebijakan pemerintah, dan individu.

Usahatani padi selain dilaksanakan di lahan sawah, ladang, tegalan juga dapat dilaksanakan di lahan rawa. Menurut data Dinas Pertanian dan Ketahanan Pangan Kabupaten Ciamis (2018), lahan rawa di Kabupaten Ciamis hanya terdapat di Kecamatan Lakbok seluas 5 hektar

Kecamatan Lakbok merupakan salah satu sentra padi di Kabupaten Ciamis. Usahatani padi di Kecamatan Lakbok dilaksanakan pada dua agroekosistem yakni sawah dan rawa. Secara teoritis usahatani pada agroekologi sawah dan rawa mempunyai risiko yang relatif tinggi. Faktor risiko juga dapat disebabkan serangan hama dan penyakit, bencana alam, iklim yang kurang menguntungkan, fluktuasi harga, dan sosial ekonomi petani menyebabkan terjadinya senjang produktivitas. Dampak ketidakpastian hasil panen akan mengakibatkan produsen enggan memasuki pasar produksi. Pengaruh perilaku demikian akan menyebabkan senjang produktivitas. Oleh sebab itu, peneliti tertarik untuk melaksanakan penelitian mengenai "Analisis Perbandingan Risiko Usahatani Padi Sawah dan Padi Rawa di Desa Sukanagara Kecamatan Lakbok Kabupaten Ciamis”.

\section{METODE PENELITIAN}

Metode digunakan adalah penelitian kuantitatif. Dengan Jenis penelitian yang digunakan adalah metode survey dengan mengambil suatu kasus di Desa Kalapasawit Kecamatan Lakbok Kabupaten Ciamis.

Sumber data yang digunakan dalam penelitian ini terdiri atas, data primer diperoleh secara langsung dari petani padi sawah dan petani padi rawa, data primer diperoleh melalui studi literatur serta studi dokumentasi.

\section{Penarikan Sampel}

penarikan sampel lokasi dilakukan secara purposive sampling, karena lahan rawa hanya ada di Kecamatan Lakbok Kabupaten Ciamis. Menurut Sugiyono (2010), “Purposive sampling adalah teknik 
penentuan sampel dengan pertimbangan tertentu".

Teknik penarikan responden dalam penelitian ini dilakukan dengan menggunakan teknik proporsional random sampling Menurut BPP Kecamatan Lakbok petani yang melaksanakan usahatani padi di Desa Sukanagara Kecamatan Lakbok Kabupaten Ciams sebanyak 1.085 orang terbagi dalam dua agroekosistem yaitu lahan sawah dan lahan rawa yang di ambil dengan rumus sloivin, petani padi di lahan sawah sebanyak 1.015 orang dan petani di lahan rawa sebanyak 70 orang.

\section{Rancangan Analisis Data}

Data yang sudah berkumpul diolah dalam bentuk tabulasi dan selanjutnya dianalisis. Alat analisis yang digunakan dalam penelitian ini adalah sebagai berikut

1. Analisis biaya dilakukan untuk mengetahui besarnya biaya tetap, biaya variabel dan biaya total, yang digunakan dalam penyelenggaraan usahatani padi. Secara matematis adalah sebagai berikut (Suratiyah, 2015) :

$\mathrm{TC}=\mathrm{TFC}+\mathrm{TVC}$

Dimana :

TC: Total Cost (biaya total)
TFC : Total Fixed Cost (biaya tetap total)

TVC : Total Variable Cost (biaya variabel total)

2. Analisis Penerimaan

Menurut (Suratiyah, 2015), untuk mengetahui total penerimaan dirumuskan sebagai berikut :

$\mathrm{TR}=\mathrm{P} \times \mathrm{Q}$

Dimana :

TR : Total Revenue/Penerimaan Total $(R p)$

$P \quad$ : Pricel Harga $(\mathrm{Rp} / \mathrm{kg})$

Q : Quantity/Produksi ( $k g)$

3. Analisis Pendapatan

Untuk mengetahui pendapatan bersih digunakan rumus analisis keuntungan (Suratiyah, 2015) :

$\pi=\mathrm{TR}-\mathrm{TC}$

Keterangan :

л $\quad$ : Profil/Keuntungan (Rp)

TR : Total Revenue/Penerimaan Total (Rp)

TC : Total Cost/Biaya Total (Rp)

4. Analisis Risiko

(a) Analisis risiko Produksi ditentukan berdasarkan nilai koefisen variasi (Heriani, dkk, 2013) :

$C V a=\frac{V a}{E a}$

Dimana :

CVa : Koefisien variasi Produksi 
Va : Sinpangan baku Produksi (kw)

Ea : Produksi rata-rata $(\mathrm{kw})$

Kriteria yang dipakai adalah sebagai berikut :

a) Nilai $\mathrm{CVa} \leq 1$ maka usahatani yang dianalisis memiliki risiko kecil.

b) Nilai $\mathrm{CVa} \geq 1$ maka usahatani yang dianalisis memiliki risiko besar.

Sebelum mengukur koefisen variasi harus mencari produksi rata-rata petani padi dan simpangan bakunya. Secara statistik risiko dapat dihitung dengan menggunakan ukuran keragaman (variance) maupun simpangan baku (standar devacition).

Adapun rumus simpangan baku yaitu : $V a=\sqrt{V a^{2}}$

Dimana :

Va : simpangan baku produksi (kw)

$\mathrm{Va}^{2}:$ keragaman produksi $(\mathrm{kw})$

Batas bawah produksi menunjukan nilai produksi terendah yang mungkin diterima oleh petani.

a) $\mathrm{L}=0$ atau $\mathrm{L} \leq 0$, maka petani mengalamii kerugian.

b) $\mathrm{L} \geq 0$, maka petani tidak akan pernah mengalami kerugian.

Rumus batas bawah Produksi (Kadarsan, 1995 dalam Heriani, dkk, 2013)

$L=E a-2 . V a$
Dimana :

L : Batas bawah

Ea : Rata-rata Produksi yang diperoleh

$\mathrm{Va}$ : Simpangan baku produksi

(b) Untuk mengetahui Risiko Harga dengan rumus :

$C V b=\frac{V b}{E b}$

Dimana :

$\mathrm{CVb}$ : Koefisien variasi harga

$\mathrm{Vb}$ : Simpangan baku harga (rupiah)/kg)

$\mathrm{Eb} \quad$ : Harga rata-rata harga (rupiah)/kg) Sebelum mengukur koefisien variasi harus mencari harga rata-rat petani padi dan simpangan bakunya. Secara statistik risiko dapat dihitung dengan menggunakan ukuran keragaman (variance) maupun simpangan baku (standar deviation).

Keragaman rumus simpangan baku yaitu :

$V b=\sqrt{V b^{2}}$

Dimana :

$\mathrm{Vb}$ : simpangan baku harga (rupiah)/kg)

$\mathrm{Vb}^{2}$ : keragaman harga (rupiah)/kg)

Batas bawah harga menunjukan harga terendah yang mungkin diterima oleh petani. Apabila nilai batas bawah harga ini sama dengan atau lebih dari nol, maka petani tidak akan pernah mengalami kerugian. Sebaliknya jika nilai batas bawah harga kurang dari nol dapat disimpulkan bahwa dalam setiap proses produksi ada 
peluang kerugian yang akan diderita oleh petani. Rumus batas bawah keuntungan (Heriani, dkk, 2013) :

$$
L b=E b-2 . V b
$$

\section{Dimana :}

L : Batas bawah harga (rupiah)/kg)

$\mathrm{Eb}$ : Harga rata-rata yang diperoleh (rupiah)/kg)

$V b$ : Simpangan baku harga (rupiah)/kg)

Dengan ketentuan tertentu Apabila :

1. Nilai $\mathrm{CV}>0,5$, maka nilai $\mathrm{L}<0$, begitu pula jika nilai $\mathrm{CV} \leq 0,5$ maka nilai $\mathrm{L} \geq 0$. Hal ini menunjukan bahwa apabila $\mathrm{VC}>0,5$ maka risiko harga pada usahatani padi yang ditanggung petani semakin besar dengan menanggung kerugian sebesar L,

2. Nilai $\mathrm{CV} \leq 0,5$ maka petani akan selalu untung atau impas dengan harga sebesar L.

(c) Untuk mengetahui Risiko Pendapatan, dengan Rumus :

$$
C V c=\frac{V c}{E c}
$$

Dimana :

CVc : Koefisien Variasi Pendapatan

Vc : Simpangan baku Pendapatan (rupiah)

\section{Ec : Pendapatan rata-rata (rupiah)}

Sebelum mengukur koefisien variasi harus mencari pendapatan rata-rata petani padi dan simpangan bakunya. Secara statistik risiko dapat dihitung dengan menggunakan ukuran keragaman (variance) maupun simpangan baku (standar deviation).

Adapun untuk simpangan baku untuk Risiko pendapatan :

$V c=\sqrt{V c^{2}}$

Batas bawah pendapatan menunjukan harga terendah yang mungkin diterima oleh petani. Apabila nilai batas bawah pendapatan ini sama dengan atau lebih dari nol, maka petani tidak akan pernah mengalami kerugian. Sebaliknya jika nilai batas bawah pendapatan kurang dari nol dapat disimpulkan bahwa dalam setiap proses produksi ada peluang kerugian yang akan diderita oleh petani. Rumus Batas Bawah pendapatan adalah :

$L c=E c-2 . V c$

Dimana :

L : Batas bawah pendapatan (rupiah)

Ec : Pendapatan rata-rata yang diperoleh (rupiah)

Vc : Simpangan baku pendapatan (rupiah) Dengan keuntungan sebagai berikut, Apabila :

1. Nilai $\mathrm{CV}>0,5$ maka nilai $\mathrm{L}<0$, begitu pula jika nilai $\mathrm{CV} \leq 0,5$ maka nilai $\mathrm{L} \geq 0$. Hal ini menunjukan bahwa apabila $\mathrm{CV}>0,5$ maka risiko pendapatan pada usahatani padi yang ditanggung petani semakin besar 
dengan menanggung kerugian sebesar L.

2. Nilai $\mathrm{CV} \leq 0,5$ maka petani akan selalu untung atau impas dengan pendapatan sebesar L.

\section{Rancangan Uji Hipotesis}

Perbedaan risiko produksi, harga dan pendapatan antara usahatani padi di lahan sawah dan rawa diuji dengan menggunakan uji t tidak berpasangan (non paired t-test). Menurut Ghozali (2012), analisis uji beda adalah membandingkan rata-rata dua grup yang tidak berhubungan satu dengan yang lain. Apakah kedua grup tersebut mempunyai nilai rata-rata yang sama ataukah tidak sama secara signifikan. Dinyatakan dengan rumus sebagai berikut :

$$
\mathrm{t}=\frac{\bar{x}_{1}-\bar{x}_{2}}{\sqrt{\frac{s_{1}^{2}}{n_{1}}+\frac{s_{2}^{2}}{n_{2}}}}
$$

\section{keterangan :}

$\bar{X} 1=$ rata-rata sampel 1

$\bar{X} 2=$ rata-rata sampel 2

$S_{1}=$ varian kelompok 1

$S_{2}=$ varian kelompok 2

$n_{1}=$ banyak subjek kelompok 1

$n_{2} \quad$ banyak subjek kelompok 2

\section{Hipotesis :}

- $\mathrm{H}_{0}=$ Tidak terdapat perbedaan risiko biaya, penerimaan, pendapatan antara usahatani padi sawah dan padi rawa

- $\mathrm{H}_{1}=$ Terdapat perbedaan risiko biaya, penerimaan, pendapatan antara usahatani padi sawah dan padi rawa

Kaidah Keputusan :

- Jika t-hitung $\leq \mathrm{t}$-tabel, maka $\mathrm{H}_{0}$ diterima

- Jika t-hitung > t-tabel, maka $\mathrm{H}_{0}$ ditolak

\section{HASIL DAN PEMBAHASAN}

\section{a. Identitas Responden}

Petani adalah setiap orang yang melalakukan usaha untuk memenuhi sebagian atau seluruh kebutuhan hidupnya dibidang bercocok tanam. Petani yang dimaksud dalam penelitian ini adalah setiap orang melaksanakan usahatani padi sawah dan padi rawa. Identitas responden yang dibahas dalam penelitian ini meliputi umur, pekerjaan, pendidikan, jumlah tanggungan keluarga dan pengalaman usahatani.

\section{b. Umur}

keseluruhan reponden pada petani padi sawah sebagian besar berusia antara 56 tahun sampai dengan 80 tahun, namun berbeda dengan petani padi rawa yang menunjukan bahwa sebagian besar petani 
berusia antara 35 tahun sampai dengan 55 tahun. Hal tersebut dapat di indikasikan bahwa petani dalam penelitian ini masih berada pada usia produktif.

\section{c. Pendidikan}

sebagian besar responden pada petani padi sawah dan padi rawa tamat Sekolah Dasar (SD). Hal ini menunjukan bahwa pada petani di Desa Sukanagara masih tergolong berpendidikan rendah. Dilihat dari frekuensi tingkat pendidikan yang paling dominan adalah tamatan Sekolah Dasar (SD).

\section{d. Jumlah Tanggungan Keluarga}

tanggungan keluarga kurang dari tiga dominan pada petani padi sawah, sedangkan tanggungan keluarga lebih dari tiga dominan pada petani padi rawa. Jumlah tanggungan keluarga berkaitan erat dengan kebutuhan keluarga, dimana semakin banyak jumlah tanggungan keluarga maka akan semakin besar pula kebutuhan tersebut.

\section{e. Pengalaman Berusahatani}

pengalaman usahatani petani padi sawah dan petani padi rawa mayoritas berada pada kisaran 5 sampai 25 tahun. Tingkat pengalaman petani merupakan salah satu faktor dalam menentukan keberhasilan berusahatani, karena biasanya pengalaman sebelumnya dapat berpebgaruh terhadap pekerjaan yang dilakukannya. Hal ini berkaitan dengan Risiko kegagalan dalam berusahatani yang begitu tinggi.

\section{f. Luas Lahan}

sebagian besar petani pada padi sawah dan petani pada padi rawa memiliki lahan dengan luas lahan garapan antara 0,04 sampai 0,50 hektar.

\section{g. Analisis Biaya Usahatani Padi Sawah dan Padi Rawa per Hektar di Desa Sukanagara Kecamatan Lakbok}

Biaya variabel pada usahatani padi di lahan rawa lebih besar dibandingan dengan biaya variabel usahatani dilahan sawah hal ini disebabkan penggunaan sarana produksi seperti benih, pupuk dan pestisida tinggi, karena dilahan rawa pada musim tanam satu sering terjadi banjir, sehingga banjir mengakibatkan penggunaan benih tinggi karena bibit yang ditanam akan banyak yang akan mati setelah terandam air lebih dari tiga hari maka petani perlu melakukan penyulaman bahkan penanaman ulang, setelah banjir surut sehingga penggunaan benih padi di lahan rawa bisa dua kali lipat dari penggunaan benih padi di lahan sawah, begitu pula penggunaan pupuk baik pupuk kimia dan organik juga tinggi, seringkali petani harus melakukan pemupukan ulang karena banjir, karna banjir akan mengakibatkan kandungan unsur hara dan 
mineral dari pupuk yang larut akan hilang terbawa arus banjir.

Berbeda dengan usahatani di musim tanam dua, penggunaan sarana produksi di lahan rawa lebih rendah jika dibandingkan dengan usahatani di lahan rawa pada musim tanam satu, terutama biaya tenaga kerja dilahan rawa pada musim tanam satu lebih besar, hal ini disebabkan karena kegiatan usahatani di lahan rawa pada musim tanam satu lebih banyak, dari penyulaman bahkan penanaman ulang, pemupukan, serta penggunaan pestisida hal ini menyebabkan penggunaan tenaga kerja lebih banyak juga. Hal ini juga berimbas pada penerimaan dan pendapatan, dengan kondisi usahatani tersebut maka penerimaan dan pendapatan usahatani padi dilahan rawa pada musim tanam satu rendah sedangkan penerimaan dan pendapatan usahatani padi di lahan rawa pada musim tanam dua lebih tinggi bahkan lebih tinggi dari pada usahatani di lahan sawah, hal ini disebabkan prosuksi padi di lahan rawa pada musim tanam dua tinggi.

$\mathrm{R} / \mathrm{C}$ di lahan rawa sangat kecil yaitu 1,02, walau dikatakan masih layak karena nilai R/C lebih dari satu namun keuntungan usahatani padi di lahan rawa hanya 0,02 rupiah dari setiap 1 satuan rupiah biaya yang dikeluarkan. Tingginya penggunaan sarana produksi dan rendahnya produksi adalah faktor utama yang menyebabkan $\mathrm{R} / \mathrm{C}$ di lahan rawa kecil, lebih kecil jika dibandingkan R/C di lahan sawah yang memiliki R/C 2,70, karean usahatani di lahan sawah produksinya tinggi.

Berbeda dengan $\mathrm{R} / \mathrm{C}$ di musim tanam dua, R/C lahan rawa lebih besar jika dibandingkan dengan usahatani padi di lahan sawah dengan nilai $\mathrm{R} / \mathrm{C}$ di lahan rawa 2,90 dan nilai $\mathrm{R} / \mathrm{C}$ lahan sawah 2,46. Dengan nilai $\mathrm{R} / \mathrm{C}$ di lahan rawa sebesar 2,90 artinya setiap biaya yang dikeluarkan sebesar 1 satuan rupiah akan menghasilkan penerimaan sebesar 2,90 atau pendapatan sebesar 1, dengan nilai $\mathrm{R} / \mathrm{C}$ usahatani padi di lahan sawah sebesar 2,46 artinya setiap biaya yang dikeluarkan sebesar 1 satuan rupiah akan memperoleh penerimaan sebesar 2,46 atau akan memperoleh pendapatan sebesar 1,46 rupiah.

Dari nilai $\mathrm{R} / \mathrm{C}$ yang diperoleh pada usahatani padi di lahan sawah pada musim tanam satu dan dua serta usahatani padi di lahan rawa pada musim tanam satu sdan dua maka dapat disimpulkan usahatani tersebut layak di usahakan, karena nilai $\mathrm{R} / \mathrm{C}$ lebih dati satu.

Rata-rata penggunaan sarana produksi pada usahatani padi sawah dan rawa di Desa Sukanagara Kecamatan Lakbok pada 
musim tanam ke satu lebih banyak dibandingkan pengunaan benih ada musim tanam dua.

Rata - rata penggunaan tenaga kerja pada padi sawah dalam musim tanam 1 dalam keluarga dan luar keluarga sebanyak $90 \mathrm{HOK} /$ ha sedangkan penggunaan tenaga kerja padi rawa sebanyak $133 \mathrm{HOK} / \mathrm{ha}$. Untuk pembayaran Upah yaitu sebesar Rp 70.000 baik untuk upah tenaga kerja di

Rata - rata penggunaan tenaga kerja pada padi sawah dalam musim tanam 2 dalam keluarga dan luar keluarga sebanyak $90 \mathrm{HOK} / \mathrm{ha}$ sedangkan penggunaan tenaga kerja padi rawa sebanyak $135 \mathrm{HKSP} / \mathrm{ha}$. Untuk pembayaran Upah yaitu sebesar Rp 70.000 baik untuk upah tenaga kerja di lahan sawah maupun rawa di anggap sama, baik laki-laki maupun wanita.

\section{h. Risiko Usahatani Padi sawah dan rawa per Hektar di Desa Sukanagara Kecamatan Lakbok Kabupaten Ciamis.}

Risiko adalah sesuatu yang dihadapi oleh petani padi dalam usahatani, namun bisa dikendalikan, Hanvood (1999), menjelaskan beberapa risiko petani yang sering terjadi pada pertanian dan dapat menurunkan tingkat pendaptan petani. Sumber risiko berasal dari perubahan iklim/cuaca, bencana alam,gangguan organisme pengganggu tanaman (hama, penyakit dan gulma), harga atau pasar . Berikut risiko usahatani padi di lahan sawah dan rawa di Desa Sukanagara Kecamatan Lakbok Kabupaten Ciamis.

\section{Risiko Produksi}

Risiko dalam usahatani adalah hal yang tidak dapat dihindarkan karena semua bentuk usaha pasti terdapat risiko didalamnya. Banyak faktor yang dapat mengakibatkan risiko atau kerugian dalam usahatani diantaranya seperti serangan organisme pengganggu tanaman, perubahan iklim dan cuaca, modal, pengalaman berusahatani. Selanjutnya untuk mengetahui tingkat risiko produksi usahatani dapat dilihat pada Tabel 20.

Tabel 1. Risiko Produksi Padi Sawah dan Padi Rawa

\begin{tabular}{lrr}
\hline \multicolumn{1}{c}{ Uraian } & $\begin{array}{c}\text { Padi } \\
\text { Sawah }\end{array}$ & \multicolumn{1}{c}{$\begin{array}{c}\text { Padi } \\
\text { Rawa }\end{array}$} \\
\hline Rata-rata Produksi (a) (Kg/Ha) & 2.480 & 745 \\
Simpangan Baku (b)(Kg/Ha) & 185 & 220 \\
Koefisien variasi (Kg/Ha) & 0,09 & 0,3 \\
Batas Bawah Produksi & 2.110 & 305 \\
\hline
\end{tabular}

Tabel 1. menunjukkan bahwa risiko usahatani di kedua agroekosistem baik di sawah maupun di rawa tergolong risiko rendah, yakni kurang dari 1. Jika dilihat lebih lanjut dari koefisien variasi nilai risiko usahatani padi sawah mempunyai risiko lebih rendah dibandingkan di lahan 
rawa. Artinya peluang kerugian yang harus ditanggung oleh petani padi di lahan rawa sebesar 0,296 kg/ha, sedangkan petani padi sawah memiliki peluang kerugian sebesar 0,075 kg/ha. Risiko produksi pada lahan rawa disebabkan petani yang mengalami gagal panen terutama pada musim tanam satu dimana curah hujan tinggi yang menyebabkan lahan menjadi tergenang. Walaupun demikian, petani tetap melakukan penanaman karena tidak mengetahui akan terjadinya banjir. Dengan demikian tingginya risiko produksi usahatani padi rawa di lokasi penelitian disebabkan oleh keadaan air yang tidak teratur. Sehingga terjadinya banjir di areal persawahan yang diiringi dengan intensitas serangan hama yang cukup tinggi dan menyebabkan kegagalan produksi. Menurut Harwood, et all (1999), risiko yang sering terjadi di sektor pertanian serta dapat menurunkan tingkat pendapatan salah satunya adalah risiko hasil produksi. Faktor risiko produksi dalam kegiatan agribisnis disebabkan adanya beberapa hal yang tidak dapat dikontrol terkait iklim,dan cuaca seperti curah hujan, hama dan penyakit.

Hama yang sering menyerang tanaman padi adalah tikus, wereng, walangsangit, dan keong mas. Serangan hama tersebut menyebabkan kerusakan tanaman padi sehingga produksi berkurang dan mengalami gagal panen.

Upaya ayang dilakukan oleh petani untuk mengendalikan serangan hama tersebut adalah dengan melakukan penyemprotan menggunakan obat-obatan kimia (insektisida dan pestisida).

Kadarsan (1995) menyebutkan bahwa risiko yang tinggi akan menyebabkan peluang kerugian bagi petani. Hal tersebut dikarenakan kurang adanya penyuluhan tentang jadwal Musim Tanam yang akan dilakukan oleh petani sehingga petani di Desa Sukanagara dalam penanaman tidak serentak sehingga hama dan penyakit mudah menyerang tanaman padi tersebut.

\section{Risiko Harga}

Selain Risiko produksi petani padi juga dihadapkan dengan adanya risiko harga dari produk yang dihasilkan. Risiko harga ditunjukkan dengan adanya fluktuasi harga, Fluktuasi harga menunjukkan adanya harga tertinggi, terendah, dan harga normal. Apabila musim panen maka risiko harganya menurun sedangkan pada musim kemarau harga naik, namun rata-rata petani menjual hasil padinya dalam bentuk gabah kering hal tersebut sangatlah membantu petani karena apabila menjual dalam bentuk kering maka harga lebih besar dari pada 
menjual dalam bentuk basah. Selanjutnya untuk mengetahui risiko harga dapat dilihat pada tabel 2 .

Tabel 2. Risiko Harga Padi sawah dan Padi rawa

\begin{tabular}{lll}
\hline \multicolumn{1}{c}{ Uraian } & \multicolumn{1}{c}{$\begin{array}{c}\text { Padi } \\
\text { Sawah }\end{array}$} & $\begin{array}{c}\text { Padi } \\
\text { Rawa }\end{array}$ \\
\hline Rata-Rata Harga (a) (Rp/Ha) & 4.174 & 4.183 \\
Simpangan Baku Harga & 37,30 & 55,18 \\
(b)(Rp/Ha) & & 9 \\
Koefisien variasi (Rp/Ha) & 0,01 & 0,013 \\
Batas Bawah Harga & 4.099 & 4.073 \\
\hline
\end{tabular}

Tabel 2. menunjukan bahwa secara umum risiko harga yang dialami oleh petani pada padi sawah lebih rendah dibandingkan dengan padi rawa. Fakta di lapangan terungkap bahwa harga gabah yang berlaku didaerah penelitian berkisar antara $\mathrm{Rp}$ 4000,- sampai dengan Rp 4300,- per kg.

Sementara itu, rendahnya risiko yang dihadapi oleh petani lebih disebabkan perilaku petani yang tidak pernah menjual hasil produksinya secara langsung. Ini sejalan dengan hasil penelitian Yusuf (2018), bahwa upaya petani di Kabupaten Pangandaran untuk meminimalisir terjadinya risiko harga adalah dengan menyimpan gabah hasil panen sebagai cadangan pangan mengingat risiko yang dihadapi oleh petani tinggi.

Ketidakpastian harga yang sulit diprediksi secara tepat menyebabkan timbulnya fluktuasi harga selain faktor spekulan yang mempermainkan harga juga disebabkan kualitas gabah yang dihasilkan tergolong rendah sehingga kurang disukai konsumen.

Risiko harga pada produksi pertanian disebabkan oleh harga pasar yang tidak dapat dikuasai petani. Hal ini terkait dengan sifat produk pertanian yang sangat dipengaruhi oleh alam. Bagi petani, hal yang menguntungkan ini belum tentu dapat dinikmatinya karena waktu produksi tidak bergantung pada petani. Pada waktu harga turun petani tidak dapat menyesuaikan volume produksi dengan segera begitupun sebaliknya pada waktu harga naik petani tidak dapat menyesuaikan volume produksi dengan segera. sehingga kerugian yang lebih besar sering kali harus dialami.

\section{Risiko Pendapatan}

Tujuan petani untuk berusahatani untuk memaksimumkan tingkat pendaptan. Risiko pendapatan terjadi pada musim panen, apabila musim panen risiko harga menurun sedangkan pada musim paceklik harga menaik, sehingga mempengaruhi risiko pendapatan yang diterima petani. Risiko pendapatan usahatani padi sawah dan rawa dapat dilihat pada Tabel 3. 
Tabel 3. Risiko pendapatan Padi sawah dan Padi rawa

\begin{tabular}{lrr}
\hline \multicolumn{1}{c}{ Uraian } & \multicolumn{1}{c}{$\begin{array}{c}\text { Padi } \\
\text { Sawah }\end{array}$} & \multicolumn{1}{c}{$\begin{array}{c}\text { Padi } \\
\text { Rawa }\end{array}$} \\
\hline $\begin{array}{l}\text { Rata-Rata Pendapatan (a) } \\
\text { (Rp/Ha) }\end{array}$ & 6.785 .560 & 1.110 .898 \\
$\begin{array}{l}\text { Simpangan BakuPendapatan } \\
\text { (b)(Rp/Ha) }\end{array}$ & 657.969 & 745.762 \\
$\begin{array}{l}\text { Koefisien variasi (Rp/Ha) } \\
\text { Batas Bawah Pendapatan }\end{array}$ & 0,12 & 0,67 \\
\hline
\end{tabular}

Tabel 3. Menunjukan bahwa petani padi sawah dihadapkan pada risiko pendapatan yang lebih rendah,dibandingkan denngan petani padi dilahan rawa. Potensi kerugian yang dihadapi oleh petani padi sawah yaitu Rp5.469.621-, per hektar dan Potensi kerugian yang dihadapi oleh petani padi rawa yaitu Rp -380.626-, per hektar. Kerugian pada usahatani padi dilahan rawa tersebut diakibatkan oleh seringnya lahan rawa tergenang banjir, sehingga petani mengalami gagal panen. Sehingga besarnyaa biaya yang dikeluarkan oleh petani terdapat pada sarana produksi, di lahan rawa sarana produksi sangatlah banyak, sarana produksi terdiri dari benih, pupuk dan pestisida.

\section{i. Analisis Uji Hipotesis}

Uji perbedaan Risiko pada usahatani padi dilahan sawah dan rawa

\section{Uji perbedaan Risiko produksi}

Uji perbedaan risiko produksi menunjukan bahwa nilai t-hitung $(-18,526)$ lebih besar daripada t- tabel $(1,978)$. Sehingga dapat disimpulkan terdapat perbedaan yang signifikan antara risiko produksi usahatani padi di lahan sawah dan rawa.

\section{Uji perbedaan Risiko Harga}

Uji perbedaan risiko harga pada usahatani padi dilahan sawah dan rawa menunjukan bahwa nilai t-hitung $(-1,007)$ lebih kecil dari t-tabel $(1,978)$. Sehingga dapat disimpulkan tidak terdapat perbedaan yang signifikan antara risiko harga usahatani padi dilahan sawah dan rawa.

3. Uji perbedaan Risiko Pendapatan usahatani padi sawah dan padi rawa

Uji perbedan risiko pendapatan pada usahatani padi dilahan sawah dan rawa menunjukan bahwa nilai t-hitung $(-7,995)$ lebih besar dari t-tabel $(1,978)$. Sehingga dapat disimpulkan terdapat perbedaan yang signifikan antara risiko pendapatan usahatani padi dilahan sawah dan rawa.

\section{KESIMPULAN DAN SARAN}

\section{Kesimpulan}

Hasil dari penelitian menunjukkan bahwa Biaya Total yang dikeluarkan pada usahatani padi di lahan sawah dan dilahan rawa di Desa Sukanagara tidak jauh berbeda, namun untuk penerimaann pada MT 1 dan MT 2 usahtani padi di lahan 
sawah lebih besar dibandingkan dilahan rawa. Sehingga pendapatan pada Usahatani padi sawah lenih besar dibandingkan pendapatan padi rawa. Risiko usahatani padi sawah lebih kecil dibandingkaan padi rawa. Hasil Analisis uji hipotesis menunjukan bahwa risiko produksi dan risiko pendapatan pada usahtani padi dilahan sawah maupun rawa berbeda secara signifikan (nyata). Sedangkan untuk risiko harga pada usahatani pada lahan sawah dan rawa tidak terdapat perbedaan signifikan (tidak nyata).

\section{Saran}

Petani sebaiknya dalam penggunaan benih menggunakan varietas unggul yang toleran terhadap genagan banjir, misalnya Impari untuk meminimalisir dampak risiko serta menghindari kerugian yang diakibatkan oleh banjir.

Pemerintah melalui dinas terkait diharapkan dapat mengadakan atau membuat pengendali banjir dan memberikan informasi inovasi dalam budidaya padi rawa yang sangat besar risikonya.

\section{DAFTAR PUSTAKA}

Dinas Pertanian Kabupaten Ciamis. 2018. Data Tanam, Panen, Produksi dan Produktifitas Padi Kabupaten Ciamis. Laporan Tahunan 2018. Ciamis.

Ghozali, I. 2012. Aplikasi Analisis Multivariate dengan Program IBM SPSS. Yogyakarta : Universitas Diponegoro.

Heriani, N., Zakaria, W. A., dan Soelaeman A. 2013. "Analisis Keuntungan Dan Risisko Usahatani Tomat Di Kecamatan Sumberejo Kabuoaten Tanggamus". Jurnal JIIA. Volume 1 No 2. Program Studi Agribisnis. Fakultas Pertanian. Universitas Lampung. Bandar Lampung.

Rahim, Abd. 2012. Model Analisis Ekonomi Pertanian. Makasar. Badan Penerbit UNM.

Sutanto, 2012. Petani dan Pertanian Indonesia.

http://www.arotanto.blogspot.co m/ 9837894nhte667.html.

Widodo. 2007. Mengatasi Permasalahan Budidaya Padi. Penebar Swadaya. Jakarta.

Sugiyono. 2010. Metode Penelitian Kuantitatif Kualitatif \& R\&D. Alfabeta; Bandung.

Suratiyah, Ken. 2015. Ilmu Usahatani . Edisis Revisi. Penebar Swadaya. Jakarta.

Yusuf N.M 2018. Strategi Ketahanan Pangan Rumah Tangga Petani Dalam Menghadapi Risiko 